\title{
Towards the construction of a mechanism supported in fuzzy logic to evaluate the viability of businesses under the Canvas model
}

Laura Daniela Acosta Contreras Universidad Distrital Francisco José de Caldas ldacostac@correo.udistrital.edu.co

Andrés Ricardo Barreto López Universidad Distrital Francisco José de Caldas arbarretol@correo.udistrital.edu.co

Carlos Enrique Montenegro Marín Universidad Distrital Francisco José de Caldas cmontenegrom@udistrital.edu.co

DOI: https://doi.org/10.21158/01208160.n84.2018.1921

Paulo Alonso Gaona García

Fecha de recepción: 10 de mayo de 2017

Fecha de aprobación: 30 de octubre de 2017

Cómo citar este artículo / To reference this article / Comment citer cet article / Para citar este artigo:

Acosta Contreras, L. D.; Barreto López, A. R.; Montenegro Marín, C. E. y Gaona García, P. A. (2018). Towards the construction of a mechanism supported in fuzzy logic to evaluate the viability of businesses under the canvas model. Revista EAN, 84, (pp. 133-151 ). DOI: https://doi.org/10.21158/01208160.n84.2018.1921

Universidad Distrital Francisco José de Caldas
pagaonag@udistrital.edu.co

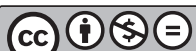

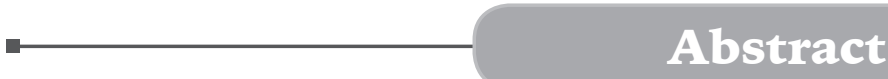

This article aims at showing the first functional approximation to the creation of a mechanism which generates a viability indicator of of a producto $r$ a business plan base don the design of Canvas model as well as using Emis Benchmarking Score as a referential issue suggested by Euromoney Institutional Inversor Company (EMIS), an organization which reveals company financial information. This approximation focuses on the application of fuzzy logic as a tool for analyzing and generating this indicator. Based on the data and information generated by a fuzzy stated system and experimental figures, a Pearson correlation coefficient was used to measure this behavioral model, resulting in 88 $\%$ which implies there is an increasing lineal relation and a variance shared proportion of $77 \%$ that makes this model feasible and its implementation follows EMIS stablished metrics.

\section{Key words}

Canvas model, fuzzy logic, EMIS, viability, correlation

Egresada del proyecto curricular Ingeniería Catastral y geodesia de la Universidad Distrital Francisco José de Caldas. Miembro del grupo de investigación GIIRA. ORCID: https://orcid.org/0000-0002-8635-9158

${ }^{2}$ Ingeniero Catastral y geodesia de la Universidad Distrital Francisco José de Caldas. Miembro del grupo de investigación GIIRA. ORCID: https://orcid.org/0000-0001-8366-7094

${ }^{3}$ Doctor en sistemas y servicios informáticos para internet de la Universidad de Oviedo, Asturias, España (2012). Tiene un Diploma de estudios avanzados 2008 de la Universidad Pontificia de Salamanca. Magíster en Ciencias de la Información y las Comunicaciones de la Universidad Distrital Francisco José de Caldas. Ingeniero de Sistemas. Director del grupo de investigación GIIRA. ORCID: https://orcid.org/0000-0002-3608-7158

${ }^{4}$ Doctor en Ingeniería de la Información y del Conocimiento, Universidad Alcalá (España), España. Ingeniero de Sistemas y Magíster en Ciencias de la Información y las Comunicaciones con énfasis en Teleinformática de la Universidad Distrital Francisco José de Caldas. Director del grupo de Investigación Multimedia Interactiva de la Universidad Distrital. Es miembro activo del grupo de investigación GIIRA Universidad Distrital, así como del grupo de investigación IERU, Universidad Alcalá. ORCID: https://orcid.org/0000-0002-8758-1412 


\section{Hacia la construcción de un mecanismo soportado en lógica difusa para evaluar la viabilidad de las empresas bajo el modelo Canvas}

Resumen. En este artículo se presenta una primera aproximación funcional de un mecanismo que permite generar un indicador de viabilidad de un producto o propuesta de negocio basado en el diseño del modelo Canvas y utilizando como referencia el Emis Benchmarking Score propuesto por el Euromoney Institutional Inversor Company (EMIS), organización que proporciona información financiera de empresas. Esta aproximación se basa en aplicación de la lógica difusa como herramienta de análisis y generadora del indicador. A partir de los datos generados por el sistema difuso planteado y de los datos experimentales, se utilizó el coeficiente de correlación de Pearson para medir el comportamiento del modelo, obteniéndose un valor del $88 \%$ que implica que existe una relación lineal creciente y con una proporción de varianza compartida del $77 \%$, lo que causa que el modelo es factible y su implementación se ajusta a las métricas establecidas para el EMIS.

Palabras clave: Modelo Canvas, lógica difusa, EMIS, viabilidad, correlación.

\section{Vers la construction d'un mécanisme supporté en logique floue pour évaluer la viabilité des entreprises grâce au modèle Canvas}

Résumé. Cet article présente l'approche fonctionnelle d'un mécanisme permettant de générer un indicateur de viabilité pour un produit ou une idée d'entreprise basé sur le modèle Canvas et utilisant comme référence l'évaluation Emis Benchmarking Score établi par Euromoney Institutional Investor Company (EMIS), organisation qui fournit des informations financières sur les entreprises. Cette approche est basée sur l'application de la logique diffuse comme outil d'analyse et de génération de l'indicateur. A partir des données générées par le système de logique diffuse et des données expérimentales, le coefficient de corrélation de Pearson est utilisé pour mesurer le comportement du modèle obtenant alors une valeur de $88 \%$ et impliquant une relation linéaire croissante et une proportion élevée de la variance partagée de $77 \%$, rendant le modèle viable grâce à une implémentation ajustée aux paramètres établis par le EMIS.

Mots clefs: Modèle Canvas, logique diffuse, viabilité, corrélation.

\section{A construção de um mecanismo suportado em lógica difusa para avaliar a viabilidade das empresas sob o modelo Canvas}

Resumo. Neste artigo apresenta-se uma primeira aproximação funcional de um mecanismo que permite gerar um indicador de viabilidade de um produto ou proposta de negócio baseado no desenho do modelo Canvas, utilizando como referência o Emis Benchmarking Score proposto pelo Euromoney Institutional Investidor Company (EMIS), organização que proporciona informação financeira de empresas. Esta aproximação baseia-se em aplicativo da lógica difusa como ferramenta de análise e geradora do indicador. A partir dos dados gerados pelo sistema difuso proposto e dos dados experimentais, utilizou-se o coeficiente de correlação de Pearson para medir o comportamento do modelo, obtendo-se um valor de $88 \%$ que implica que existe uma relação linear crescente e com uma proporção de variância compartilhada de $77 \%$, o que causa que o modelo é factível e sua implementação se ajusta às métricas estabelecidas para o EMIS.

Palavras-chave: Modelo Canvas, lógica difusa, Emis, viabilidade, correlação. 


\section{Introducción}

$\mathrm{E}$ ntrepreneurship in the world is a driving force behind the economic growth of a country, at least, this is what the Global Entrepreneurship Monitor (GEM) report says, which is made on a yearly basis with the purpose of presenting «the measurement of entrepreneurship and the identification of factors that, at the institutional, cultural, regulatory, and public policy level, determine the level of entrepreneurial activity" (Global Entrepreneurship Monitor, 2015). The report carried out in the period of 2015-2016 covers 61 economies around the world (Kelley, Singer, \& Herrington, 2015).

Within the highlights of the report, it pointed to the good social and economic perception of people engaged in this activity. It draws attention to the need for agencies to offer opportunities, benefits, and economic support to these businesses, as these initiatives are the basis for having strong and competitive economies. Thus, it becomes necessary to provide these organizations with tools that can validate the business proposals in an agile way and with a high level of certainty.

So, making the correct decisions becomes the key to success for entrepreneurs, however, it is difficult to envision a model that can guide the proposition of a business idea to a successful outcome. For this reason, a tool that allows strengthening the decision-making of both investors and entrepreneurs is proposed; from the integration between the fuzzy logic and the use of the canvas model. The objective is to generate a first indicator of viability that will indicate whether it is advisable to deepen into the business idea. The proposed model can be applied to any organization, given that the goal of the canvas tool is to represent a general view of the business, and the goal of the fuzzy system is to weight the data and generate the associated indicator.

Initially, the EMIS Benchmarking Score -formerly known as ISI Emerging Marketsis taken as a reference for the construction of this tool (Euromoney Institutional Inversor Company, 2017), in companies that are established in the market, with the purpose of visualizing the behavior of the system with organizations that are already shaped, and assess the level of reliability of the proposed model.

The uses of a fuzzy logic system and of the principles of the Canvas tool were suggested in order to generate theoretical data that will enable the comparison between the theoretical results and the behavior of the selected indicator. 


\section{Background}

\subsection{Associated to Fuzzy logic rules}

Fuzzy Logic is an effective tool that allows to set on the basis of qualitative criteria a series of quantitative values (Zadeh, 1975). This means that they are generated degrees of belonging for the variables considered in uncertainty and imprecision environments where it is difficult to work with restrictive values, generating estimates with value and meaning. Zadeh (2008) define fuzzy logic is a precise logic of imprecision and approximate reasoning. The declaration of rules in natural language and definition of membership functions allow modeling the behavior of a system

The first person in introduced the terms fuzzy logic and fuzzy sets was professor of the University of Berkley California Lofti Zadeh in 1965 in his paper «Fuzzy Sets», and he is considered the father of fuzzy logic. In his first work he points out the need to handle values outside the classical theory of sets, so it proposes criteria of partial membership more false - more true-, are called fuzzy sets (Zadeh, 1965). The process performed in a fuzzy logic system is presented in Figure 1, the variables that are going to be used in the fuzzy model are configured in the parameterization; once it is established, the modeling of the fuzzy model is started. The rules and operands that allow the behavior of each of the input variables are set, with the purpose of observing the degree of membership for the input values with which the desired quantitative output is obtained with the defuzzification process.

Figure 1. Fuzzy Inference Scheme

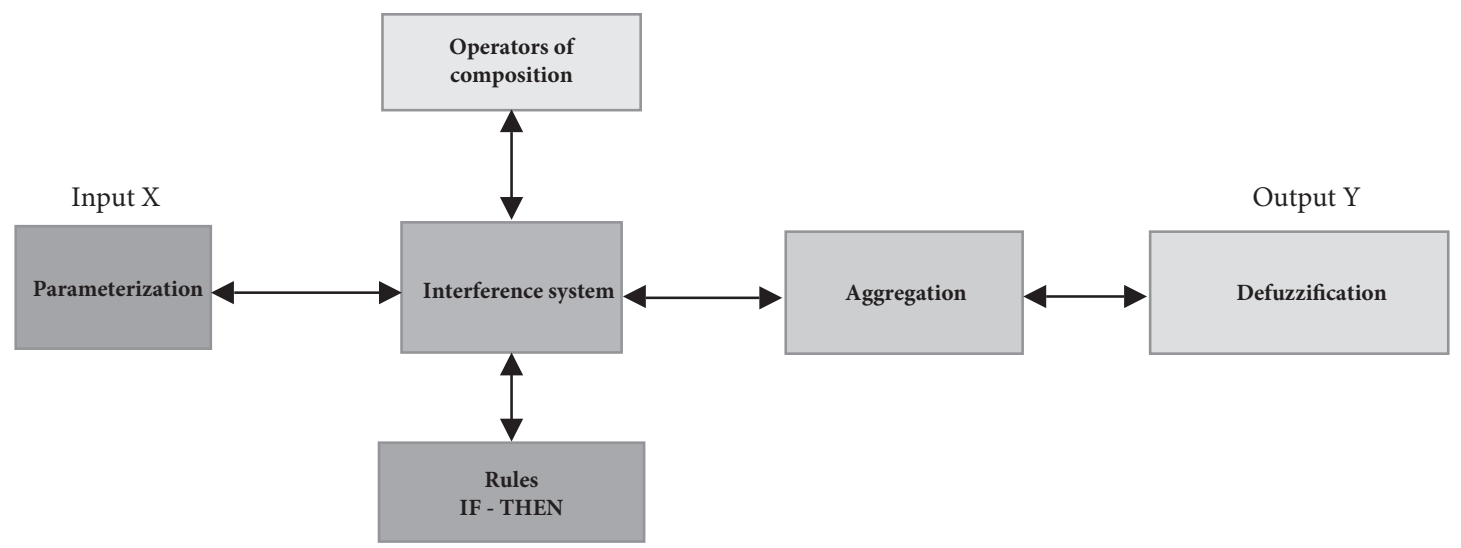

Source. Jimenez (2013). 


\subsection{Business Model Canvas}

The Business Model Canvas is a tool methodological composite for nine blocks qualitative in which it is proposed to map the activities that can form a business proposal, describing «the basics of how an organization creates, develops, and capture value» (Osterwalder, \& Pigneur, 2011). The modules defined are (Figura 2):

- Market segments: they present the groups in which the business entered, it can be one or more segments.

- Value propositions: it refers to the set of products or services that allow a business to meet the needs of its clients; it represents the company's sentimental value that is unique and different from its competitors.

- Channels: it is the way of establishing contact with the market segment of the business with the purpose of facilitating the purchase of the product or service, being bridges that allow to evaluate the value proposition and after-sale service.

- Relationships with customers: the types of relationships that are established with the customer segment, in order to attract, retain, or encourage their participation in the market.

- Source of income: revenues are the result of the value propositions offered to the customers.

- Key resources: these are the assets -physical, financial, intellectual, or human- that are necessary for the company to perform all the creation, development, and capture of value.

- Key activities: the main activities that must be executed for the development, distribution, and sale of the value proposition of the organization.

- Key societies: it is important to have some outsourced activities -satellites, outsourcing, conventions, etc.-, and shared activities in order to strengthen the business model and the market.

- Structure of costs: costs are bound to create, develop, and capture value, and they vary according to the business model approach.

Figure 2. The business canvas model

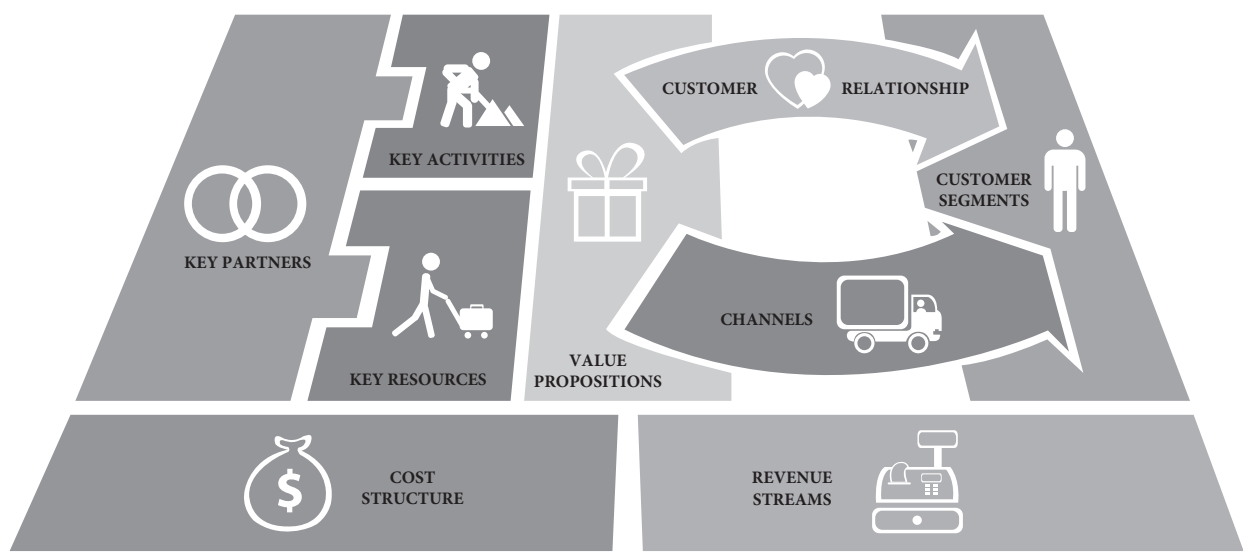

Source. Osterwalder \& Pigneur (2011). 
Euchne \& Ganguly (2014) point out that innovation is usually accompanied by a significant degree of risk, for this reason exists the need to minimize the risks associated with the generation of business models. Therefore, even though the canvas model exposes a global view of the qualitative composition of the business, that is to say, presents the basic conditions of the proposal and its composition, it is difficult to establish its viability; since it is not possible to establish a quantitative results analysis that provides a first indicator, before carrying out a feasibility study.

In consideration of the above, the object of this study focuses on the design of a fuzzy logic system that generate a feasibility indicator for the business proposal, from the behavior of the activities defined within the canvas model.

\subsection{Related work}

Based on the state of the art associated with this case study, there was not found a formal or direct application of integration between model canvas and fuzzy logic. However, there is a large bibliographic content in economic and business management environments that contribute significantly to this proposal. Among the contributions found, the following are presented.

Rojas, Zuluaga, and Valencia (2014), propose a fuzzy system that allow evaluate enterprises from corporate valuation techniques with the purpose of establishing impact variables. Based on this analysis, it would be possible to propose a system that would allow to determine whether it is feasible or not to invest in a company based on its behavior on macroeconomic, internal competencies, and monetary powers, however, one of the weaknesses present in this study is that the model is without a deployment so that makes it difficult to establish its viability.

Cortina and Robaina (2010), established the need to develop methods of quantitative analysis to identify criteria accompanied by some level of uncertainty, in order to generate greater assertiveness in decision-making; for this, they proposed a series of joint operations, setting the relationship of the qualitative control made by the dialectic which is characteristic of the human being. Given that establishing logic through the dialectic is a complex process with the traditional tools, the use of techniques such as fuzzy mathematical and the calculation of the criteria of truth is proposed, establishing that such criteria are not necessarily true or false, but that on the contrary, coexist in the Most False or True depending on the circumstances of the case.

According to Rojas, López, and Rincón (2012), in order to perform the calculation of indicators, the measurement indicators should be set; indicator understood as the level of behavior of a variable, and as how to index the limits or ranges for the construction of the study. This is a control system for the evaluation of Cybersim management using the method with which the parameter identification indexes as fuzzy sets and values of belonging, as well as the structured results indicator in the base of knowledge with definitions of liability rules from the evaluator; highlighting the importance of professional judgment to measure levels of management in the applied case.

Angarita, Tabares, and Rios (2015), point to the need of improving the security systems with which the information generated on the Internet is protected. With the use of fuzzy systems the ambiguity generated in the risks evaluation can be treated, as they 
provide metrics that can have a greater level of certainty with respect to the base of the knowledge, outlining to the fuzzy logic as a tool for modeling control systems, from qualitative to quantitative scales.

Gonzalez-Santoyo, Gil-Lafuente, and Flores Romero (2015), set out the importance of the budget for a project to raise the uncertainty that exists from the different options that are generated at the time of projecting it and running it. They identify the importance of the management of the treasury, where it is exposed that the payment varies in relation to different factors of the market -competition clients - regulations-, for this reason they use the zero-based budget ( $\mathrm{ZBB})$ as an outline budget that generates a fuzzy system to select the most relevant budget option according to the needs of the organization. Additionally, they identify that in the selection of a budget it is necessary to see which is more appropriate not more likely, therefore, they conclude that the probability is not a good tool within the generation of a ZBB (zero-based budgeting)

Kolomvatsos, Anagnostopoulos, and Hadjiefthymiades (2012), describe a Fuzzy Logic System (FLS) where the behavior of a buyer in a negotiation process is modeled by identifying the dynamics that exist for the assessment of the proposal given by the seller. The purpose of the system is to reach the greatest number of successful agreements, on the basis of a comparative analysis. The authors conclude that the FLS presented generates the greatest number of agreements compared with other models.
Guerra et al. (2014), make use of the business model Canvas and the tool Lean Launchpad in the educational environment, with the aim of fostering entrepreneurial mindsets in the educational community, with the development of the pilot Body of Innovation for Learning (I-Corps-I). The objective of this proposal is to promote a wide acceptance of its products and innovative approaches in the participants, and allow the computer to determine the applicability of the I-Corps model for the propagation and expansion of educational innovations.

Proença, Nadali, and Borbinha (2015) identify the risks that the data in an organization are exposed to, with the purpose of identifying the kind of check-up to be carried out and its cost, this in order to reduce the long-term threats and increase the gain. From the use of the model canvas, they also identify the risks to which they are exposed to by block, and the controls that are generated for each of the scenarios.

Romero, Villalobos, and Sanchez (2015), set out the need to implement dynamic systems for the business model canvas with the purpose of enriching the proposals generated, identifying the variables and constants that may be involved in its preparation. The proposed model identifies three flows and three transformation processes, together with the modification of the blocks of key resources and channels, with the aim of improving the information management within each block. The opening of the canvas to dynamic elements provides a much more accurate view of the business model object of study. 


\section{Application case}

$\mathrm{O}$ sterwalder and Pigneur (2011), identify the four most important areas of the

forces that influence the design of the business environment, this, to better understand the model. Each of these areas identifies the forces that are involved (Figure 3).

Figure 3. Environment areas of the business model

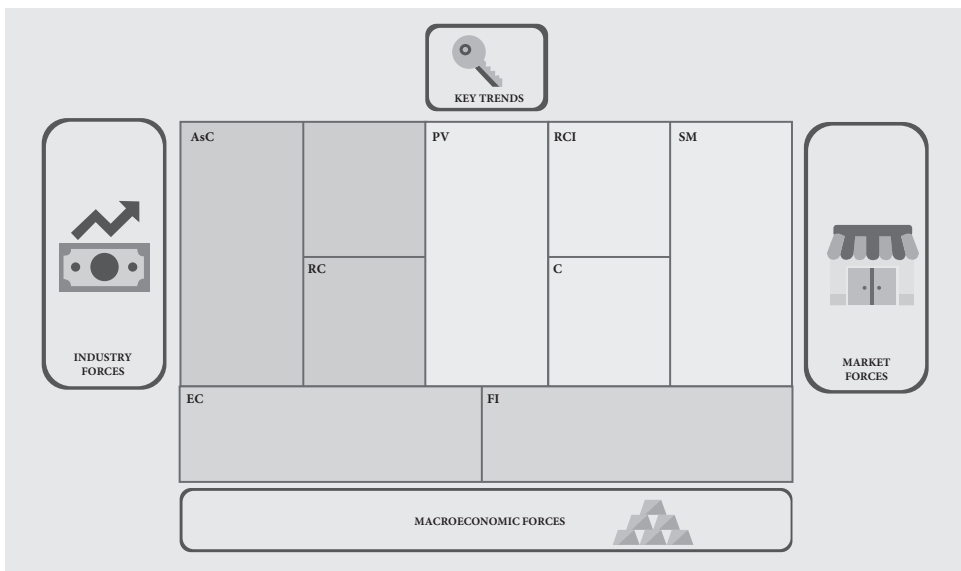

Source. Osterwalder \& Pigneur (2011).

The four areas identified are:

- Forces of the industry: this area identifies and describes what actors there involved or who may enter the environment of the business model developed, with the purpose of identifying possible key partnerships, and direct and indirect competitors.

- Macroeconomic forces: it identifies the conditions of the global market by presenting the needs of capital, commodities, and other resources that are necessary for business, oriented to the construction of the economic infrastructure of the local market.

- Market forces: it identifies issues of the segmented market according to the aspects that impulse it, presenting the needs and demands aimed at defining the behavior of the customers, with the purpose of measuring their capacity, need, and desire level to purchase.
- Key trends: it identifies the technological, regulatory, cultural, and socio-economic trends, which may affect the development of the business model.

Based on the identification of the environment areas presented by Osterwalder, it is evident that the characteristics of the key trends are clearly defined within the macroeconomic and market forces. Therefore, the proposal is to restructure this area.

In order to make the fuzzy logic system, the forces of the industry, the market forces, and the macroeconomic forces are identified in the model as a product, customers, and utility, respectively, for the purpose of controlling the behavior of the system. The value proposal is identified within the utility variable since the basis of the analysis that is performed is a source of value. The grouping was conducted as presented below (Figure 4). 
Figure 4. Grouping of the Canvas model modules

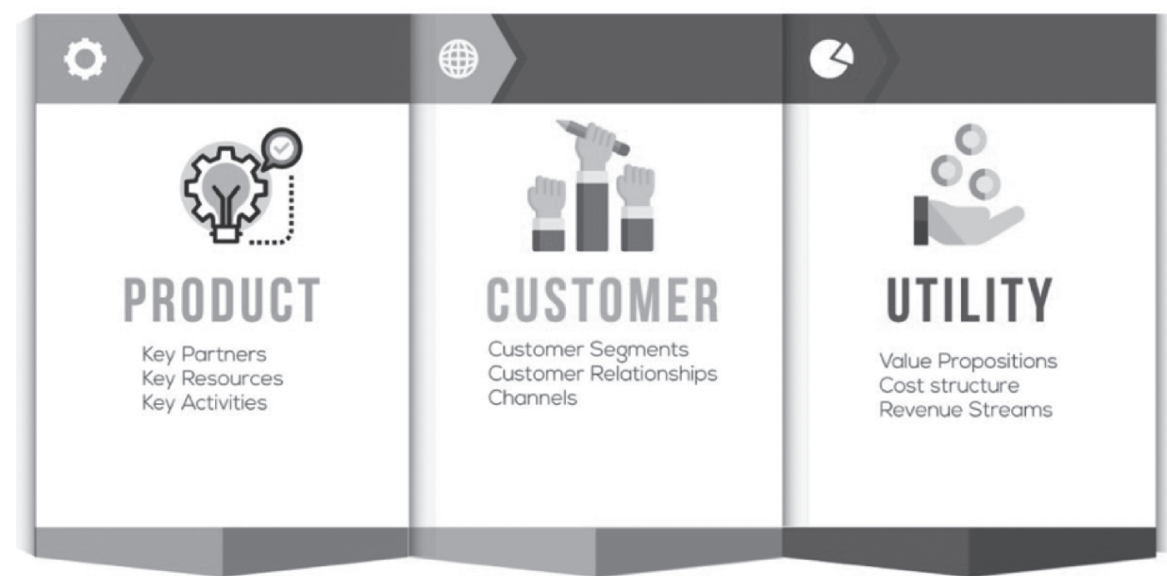

Source. Prepared by the authors.

\section{Implementation}

\subsection{Membership functions}

For the implementation, the Matlab fuzzy logic simulator was used, where the Mamdani modeling type for system fuzzy control is shown here (Figure 5).

Figure 5. Proposed system of fuzzy control

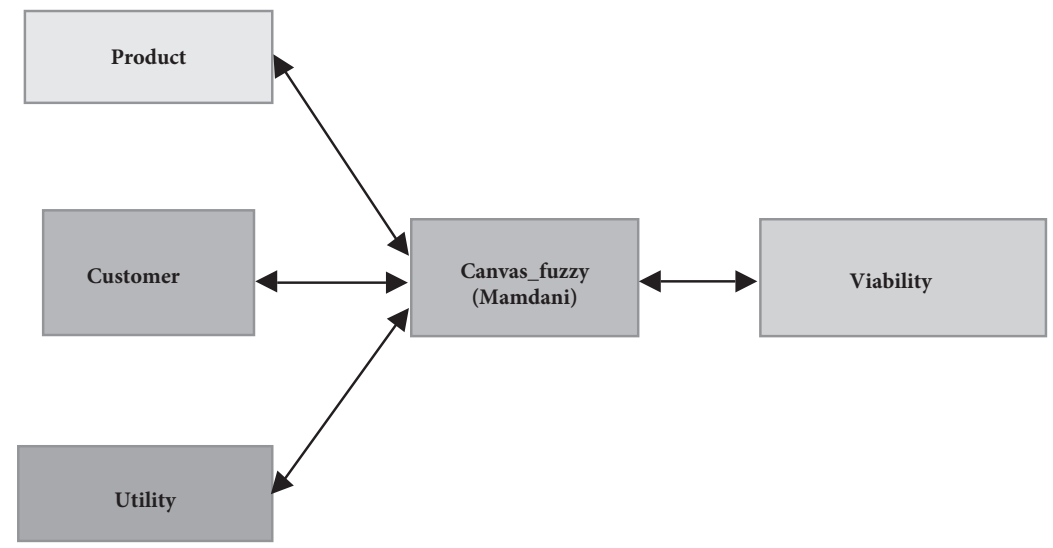

Source. Prepared by the authors according to modeling in Matlab. 
According to the knowledge base that was generated in the identification and design of the variables of the system presented previously, raises the proposal of the behavior

Figure 6. Product behavior

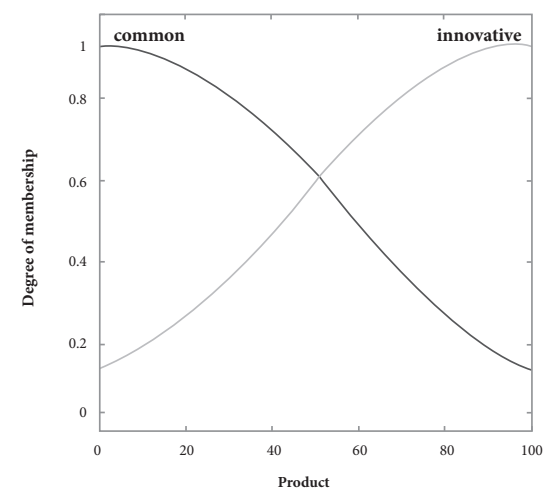

Source. Prepared by the authors according to modeling in Matlab.

For the behavior of the product variable presented adove, we selected a trend graph similar to the one for Supply and Demand. From the relationship, it was possible to establish that this graph allows to simulate the behavior of the product where its market share is measured, validating that if the competition is smaller, the greater its potential of participation. Depending on the fuzzy value generated for this variable and the parameters involved, the objective is to determine if the product is common or innovative. Membership functions are in equation 1 and 2 :

$$
\begin{gathered}
\text { Common }=f(x ; 50,0)=e^{\frac{-(x-0)^{2}}{\left(2(50)^{2}\right.}} \\
\text { Innovative }=f(x ; 50,100)=e^{\frac{-(x-100)^{2}}{\left(2(50)^{2}\right.}}
\end{gathered}
$$

graphs for each entry in consonance with the analysis of the established variables for the system, (Figure 6; Figure 7).

Figure 7. Customer behavior

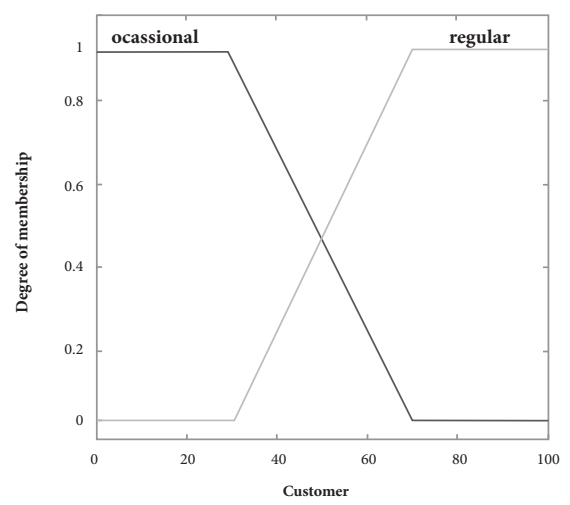

Source. Prepared by the authors according to modeling in Matlab.

Now, for the behavior of the customers' variable presented, a trapezoidal graph was selected, since its slopes and stability points allow us to simulate the level of ambiguity and volatile behavior of the customer within the market. If it belongs to the segment, it is established as an occasional customer but does not interact with the goods or service, while the regular customer actively participates in the acquisition of the product; this is defined according to the behavior in the market and depending on the segmentation, communication, and the relationship between buyer and seller. Membership functions are in equation 3 and 4 :

ocassional $=f(x ; 0,0,30,70)=\max \left(\min \left(\frac{x-0}{0-0}, 1, \frac{70-x}{70-30}, 0\right)\right.$

regular $=f(x ; 30,70,100,100)=\max \left(\min \left(\frac{x-30}{70-30}, 1, \frac{100-x}{100-100}\right), 0\right)$ 
Figure 8. Behavior of the utility

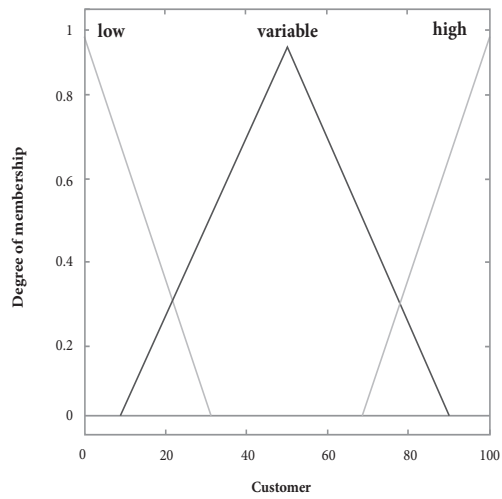

Source. Prepared by the authors according to modeling in Matlab.

For the behavior of the utility variable presented (Figure 8), a triangular graph is selected, depending on the fuzzy value generated for this variable and the parameters involved, the objective is to determine if the utility will be low, variable, or high. This type of graph is selected since it allows the simulation of increasing and decreasing behavior within the market behavior and fluctuation peaks that simulate the utility ceilings. Membership functions are in equation 5, 6 and 7 :

$$
\begin{gathered}
\text { Low }=f(l ; 0,0,30)=\max \left(\min \left(\frac{l-0}{0-0}, \frac{30-l}{30-0}\right), 0\right) \\
\text { Variable }=f(x ; 10,50,90)=\max \left(\min \left(\frac{x-10}{50-01}, \frac{90-x}{90-50}\right), 0\right) \\
\text { High }=f(x ; 70,100,100)=\max \left(\min \left(\frac{x-70}{100-70}, \frac{100-x}{100-100}\right), 0\right)
\end{gathered}
$$

The output of the system presents a triangular graph with four states to simulate the behavior and transition between the different viability indicators of the model to be evaluated, (Figure 9), and whose membership functions are in equations $8,9,10$ and 11 :
Figure 9. The output of the fuzzy system

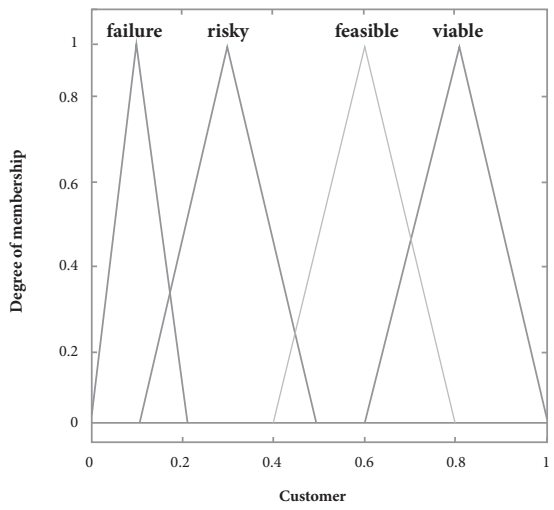

Source. Prepared by the authors according to modeling in Matlab.

$$
\begin{gathered}
\text { Failure }=f(l ; 0,0.1,0.3)=\max \left(\min \left(\frac{l-0}{0.1-0}, \frac{0.3-l}{0.3-0.1}\right), 0\right) \\
\text { Risky } \left.=f(x ; 0.1,0.3,0.5)=\max \left(\min \left(\frac{x-0.1}{0.3-0.1}, \frac{0.5-x}{0.5-0.3}\right)\right), 0\right) \\
\text { Feasible }=f(x ; 0.4,0.6,0.8)=\max \left(\min \left(\frac{x-0.4}{0.6-0.4}, \frac{0.8-x}{0.8-0.6}\right), 0\right)
\end{gathered}
$$

Viable $=f(x ; 0.6,0.8,1)=\max \left(\min \left(\frac{x-0.6}{0.8-0.6}, \frac{1-x}{1-0.8}\right), 0\right)$

\subsection{Fuzzy rules}

The scenarios are identified with the objective of obtaining the respective antecedent and consecutive for the construction of the fuzzy rules that are indicated next, in the behavior of the input variables product (p), customer (c) and utility (u), and the output variable viability (v).

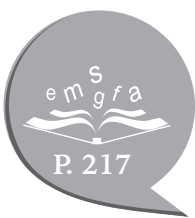


Table 1. Fuzzy rules

\begin{tabular}{|c|c|}
\hline Rule & Fuzzy rules \\
\hline 1 & if (p) is common, and (c) is regular, and $(\mathrm{u})$ is low, then $(\mathrm{v})$ is failure. \\
\hline 2 & if (p) is common, and (c) is regular, and $(\mathrm{u})$ is variable, then (v) is risky. \\
\hline 3 & if (p) is common, and (c) is regular, and (u) is high, then (v) is risky. \\
\hline 4 & if (p) is common, and (c) is occasional, and (u) is low, then (v) is risky. \\
\hline 5 & if (p) is common, and (c) is occasional, and (u) is high, then (v) is feasible. \\
\hline 6 & if (p) is innovative, and (c) is regular, and (u) is low, then (v) is failure. \\
\hline 7 & if (p) is innovative, and (c) is regular, and (u) is variable, then (v) is risky. \\
\hline 8 & if (p) is innovative, and (c) is regular, and (u) is high, then (v) is feasible. \\
\hline 9 & if (p) is innovative, and (c) is occasional, and (u) is low, then (v) is feasible. \\
\hline 10 & if $(\mathrm{p})$ is innovative, and $(\mathrm{c})$ is occasional, and $(\mathrm{u})$ is variable, then $(\mathrm{v})$ is viable. \\
\hline 11 & if (p) is innovative, and (c) is occasional, and (u) is high, then $(v)$ is viable. \\
\hline
\end{tabular}

\section{Primary data}

$I^{\prime}$ n order to validate the functionality of the system, it is necessary to make a comparison with existing metrics that display the currently formalized position of the organizations in the market, with the purpose of comparing it with the one generated by the fuzzy logic system.

Based on the business models of existing organizations and adjusted to the base of the knowledge that has been generated, it is proposed to stabilize the model in order to provide greater reliability to the fuzzy system pro assessing business models of future companies that must be evaluated.

For this, the EMIS Benchmarking Score proposed by the Euromoney Institutional Investor Company (EMIS), is selected. The EMIS is an organization that delivers information from more than 100 emerging markets

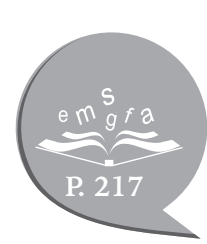

(EMIS Benchmark, 2017), with up-to-date information based on different metrics and on the market behavior. This is a private, for-profit organization, which gives a score to each company that it tracks, indicating the corporate viability of each organization.

A preliminary basis of 30 companies with the highest market capitalization according to the Colombian Value Stock for March of year 2017 (Bvc.com.co, 2017) was selected to validate the implementation. For the study, we chose those that have the indicator generated by EMIS (Table 2), and created abbreviations for the companies by using the first letter of each word in the company's name, or the first letters in those cases where the name of the company was too long.

Validation is performed with existing companies from the hypothesis, that are already qualified and who are models of stable businesses in the market. In pursuance of adjusting the model with the reality of these organizations, we can say that the system is stable and can be implemented for the evaluation of new projects. 
Table 2. Companies associated to the study

\begin{tabular}{|l|c|c|}
\hline \multicolumn{1}{|c|}{ Companies } & $\begin{array}{c}\text { Abbreviations for the } \\
\text { companies }\end{array}$ & Emis \\
\hline Ecopetrol S.A. & ECO & 41,95 \\
\hline Empresa De Energía De Bogotá S.A. E.S.P. & EEB & 81,41 \\
\hline Interconexión Eléctrica S.A. & INTER.ELEC & 71,18 \\
\hline Cementos Argos S.A. & CEMEN.ARG & 72,61 \\
\hline Isagen S.A. & ISAGEN & 69,84 \\
\hline Almacenes Éxito S.A. & ÉXITO & 73,73 \\
\hline Cemex Latam Holdings S.A. & CEMEX & 68,53 \\
\hline Promigas S.A.E.S.P. & PROMIGAS & 76,19 \\
\hline Empresa De Telecomunicaciones De Bogotá S.A.E.S.P. & ETB & 46,92 \\
\hline Empresa De Energía Del Pacifico S.A. E.S.P. & EEP & 58,93 \\
\hline Productos Familia S.A. & FAMILIA & 78,87 \\
\hline Organización Terpel S.A. & TERPEL & 69,27 \\
\hline Organización De Ingeniería Internacional S.A. & OII & 68,36 \\
\hline Constructora Madera Y Concreto S.A.S. & CONS.MYC & 44,59 \\
\hline
\end{tabular}

Source. Prepared by the authors with the indicators given by the EMIS (Euromoney Institutional Investor Company, 2017).

\section{Results}

$\mathrm{T}$ he Canvas model of the fourteen organizations is presented (Table 3), by weighting each of the nine blocks with values from 0 to 1 , depending on the established metrics in the fuzzy control chart assigned to each group (Figure 6; Figure 7; Figure 8).

After that, (Figure 4), the grouping of blocks is made with the purpose of generating the average value of the components of each group.

In order to identify the values to be entered in each of the blocks of the Canvas model and for the construction of the knowledge base, an investigation of the evaluated companies was performed according to their behavior in the market, in the direction of obtaining the overview of the business model to perform the weighting of the Canvas model.

The viability indicator presented (Table 3 ), is the result obtained from the fuzzy logic system for each organization based on the weighted values of each group in the canvas. The defuzzification method used was Centroid, which returns the center of area under the curve (Fogel, Liu, \& Keller, 2016). 
Laura Daniela Acosta Contreras / Andrés Ricardo Barreto López / Carlos Enrique Montenegro Marín / Paulo Alonso Gaona García

Table 3. Results of the canvas model for the selected companies with their abbreviations

\begin{tabular}{|l|c|c|c|c|}
\hline Abbreviations of the companies & Product & Customer & Utility & Viability (Fuzzy) \\
\hline ECO & 50,1 & 45,0 & 70,6 & 0,529 \\
\hline EEB & 71,0 & 75,0 & 51,1 & 0,800 \\
\hline INTER.ELEC & 87,0 & 62,9 & 91,0 & 0,659 \\
\hline CEMEN.ARG & 41,1 & 95,7 & 61,2 & 0,789 \\
\hline ISAGEN & 91,0 & 62,4 & 89,0 & 0,654 \\
\hline ÉXITO & 51,1 & 78,9 & 79,1 & 0,700 \\
\hline CEMEX & 69,1 & 81,7 & 71,2 & 0,724 \\
\hline PROMIGAS & 63,3 & 68,7 & 55,0 & 0,769 \\
\hline ETB & 65,5 & 55,0 & 88,5 & 0,586 \\
\hline EEP & 70,1 & 55,0 & 70,6 & 0,570 \\
\hline FAMILIA & 59,1 & 96,0 & 91,1 & 0,712 \\
\hline TERPEL & 70,4 & 65,0 & 73,5 & 0,638 \\
\hline OII & 69,0 & 86,0 & 97,0 & 0,726 \\
\hline CONS.MYC & 56,0 & 47,0 & 46,0 & 0,525 \\
\hline
\end{tabular}

Source. Prepared by the authors according to the values given by the fuzzy logic system modeled in Matlab.

\section{Comparison of the results}

Titially, a calculation of basic metrics of the 1 model and of the EMIS indicator is made, and a statistical analysis was performed in the direction of establishing the comparison of the survey results (Table 4).

Table 4. Statistical values

\begin{tabular}{|c|c|c|}
\hline Measurements & EMIS & FUZZY \\
\hline Medium & 69.555 & 67.95 \\
\hline Median & 65.884 & 67.01 \\
\hline Variance & 151.804 & 77.81 \\
\hline Deviation & 12.786 & 9.15 \\
\hline
\end{tabular}

Source. Prepared by the authors according to the data obtained in Table 2 and Table 3.
From the statistical variables, the dispersion analysis of data is generated, identifying the levels of bias and relational behavior in the indicators that were generated by the selected sources.

For the comparison of the results, the first action was to establish the relationship between the values of the EMIS and those obtained in the fuzzy system, using the data in tables 2 and 3, to graphically represent the relationship.

From the results presented (Figure 10), we can evidence the relational behavior between the theoretical values generated in the fuzzy system and the actual values of the indicator generated by EMIS. It is possible to identify a correlation between the results of the study according to the trend line. 
Figure 10. Relationship between the EMIS indicators and the fuzzy model

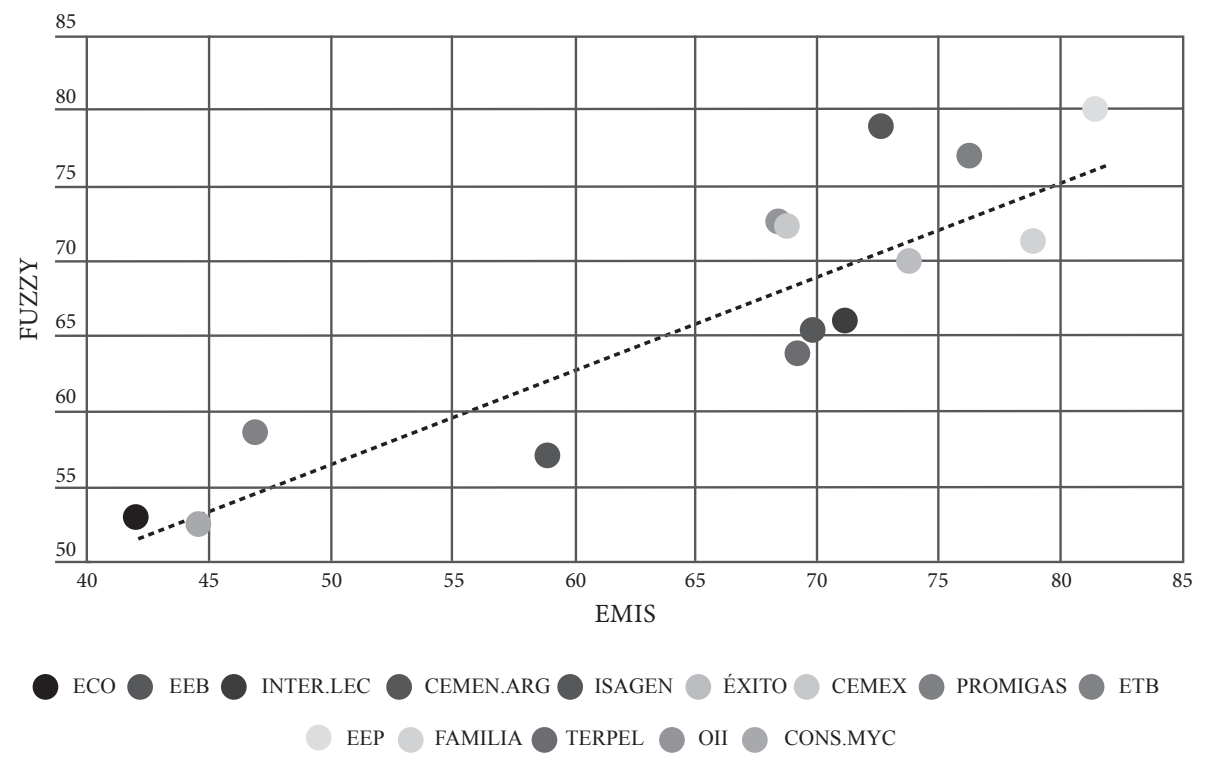

Source. Prepared by the authors.

The next informatión (Figure 11), establishes the behavior of the values that were obtained through the statistical analysis that was carried out, it identified the values that are found inside and outside the range of dispersion generated by the fuzzy system and the EMIS, which have a stable behavior according to the ranges of deviation.
So, it was established for each group of values, which should be considered unfit, for the purpose of identifying those that can reduce the viability of the system. In the case study, all values will be considered.

Figure 11. EMIS and Fuzzy System Behavior

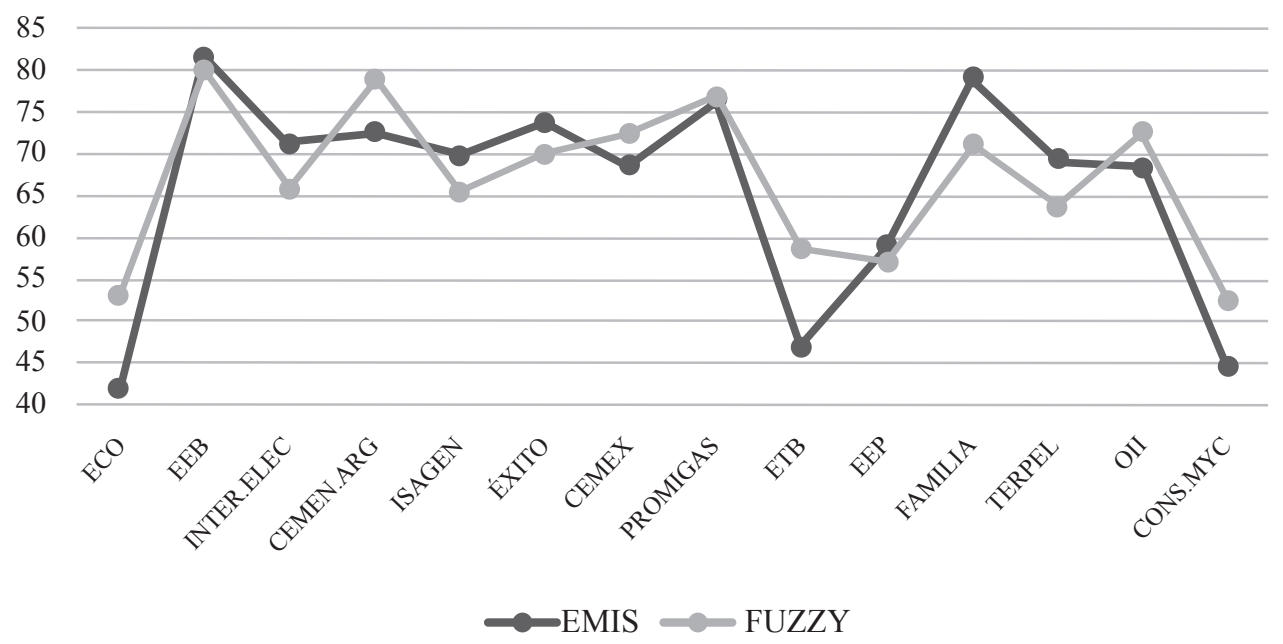

Source. Prepared by the authors according to values in Table 2 and Table 3. 
Using the Pearson correlation coefficient, with the purpose of establishing if there is correspondence between the indicators provided by the fuzzy model and the EMIS indicator represented (Figure 10), which initially pointed out a linear trend growing in the relationship.

The formula used for the calculation of the correlation (Johnson \& Kuby, 2012) is presented in equation (1):

$$
r=\left(\frac{S S(x y)}{\sqrt{ }(S S(x) S S(y)}\right)
$$

From this, the calculation for each of the variables to compromise is performed, according to the formulas established in equations (2), (3) and (4):

$$
\begin{aligned}
& S S(x)=\sum x 2-\frac{\left(\sum x\right) 2}{n} \\
& S S(y)=\sum y 2-\frac{\left(\sum y\right)^{2}}{n} \\
& S S(x y)=\sum x y-\frac{\sum x \sum y}{n}
\end{aligned}
$$

The replacement of the values in equation (1) is made, in order to find the value of the correlation coefficient, where it is set as $r=$ 0,882108076 . This value indicates that there is a linear correlation between the two variables. However, you must perform the validation that the variables $\mathrm{X}$ and $\mathrm{Y}$ are truly related, that is to say that this correlation was not the result of a coincidence, for this can be from two scenarios:
$H_{0}: r=0=>$ The correlation coefficient comes from a population whose correlation is zero ( $\rho=0$ (correlation coefficient))

$\mathrm{H}_{1}: \mathrm{r}=0=>$ The correlation coefficient comes from a population whose correlation is zero $(\rho \neq 0$ (correlation coefficient))

With the established hypothesis, it must be checked if the correlation coefficient that has obtained is within the sampling distribution offered by the null hypothesis. It is calculated as the number of standard deviations that are found in the center of the distribution (Kenney, 1966) according to equation (5):

$$
t=\frac{r_{x y}-0}{\sqrt{\frac{1-r_{x y}^{2}}{N-2}}}
$$

The value that was obtained is compared with the ones existing in the tables for a certain level of significance $a$ and $\mathrm{N}-2$ degrees of freedom $t_{(a, N-2)}$, as follows:

$\mathrm{T}>\mathrm{t}_{(a, \mathrm{~N}-2)}$ rejects the null hypothesis. The correlation does not come from a population whose value is $\rho=0$; therefore, the variables are related.

$\mathrm{T} \leq \mathrm{t}_{(a, \mathrm{~N}-2)}$ accepts the null hypothesis. The correlation comes from a population whose value is $\rho=0$; therefore, the variables are not related.

The replacement in equation (5) is done with the data that is known, $\mathrm{t}=6,487062974$. Looking in the table T-Student for $\mathrm{a}=0.05$ and $14-2=12$ degrees of freedom, where the value is 2,179 .

The null hypothesis is rejected, the correlation was obtained between the two indicators where $6,487>2,179$, which is not appropriate for a population that is characterized 
by a correlation of zero. That is to say, this correlation is not just a coincidence, this we guarantee with an estimated error of 0.05 .

After obtaining the correlation, we make the calculation of the proportion of variance shared, which is referred to as coefficient of determination, and whose correlation square is $r^{2}$ (Kenney, 1966), achieving value of the $77 \%$.
Finally, the calculation of the typical error (Marqués, 2009) of the data, according to equation (6):

$$
\sqrt{ }\left[\frac{1}{n(n-2)}\right] *\left[n \sum y^{2}-\left(\sum y\right)^{2}-\frac{\left[n\left(\sum x y\right)-\left(\sum x\right)\left(\sum y\right)\right]^{2}}{n \sum x^{2}-\left(\sum x\right)^{2}}\right]
$$

Getting results of a typical error of $S_{y x}=6.3$ units.

\section{Conclusions}

$\mathrm{T}$ he integration of a fuzzy logic system with the canvas model tool for the evaluation of projects, generated a percentage of correlation of $88 \%$, which implies that the indicator offered for the tool and the EMIS indicator has a positive linear correlation, presenting the proposed system as a tool to be taken into account for the generation of a first indicator of viability in the evaluation of business models.

From the data that are outside of the deviation bounds, we were able to identify that it is necessary to adjust the metrics for the assignment of values to the canvas model in order to improve its effectiveness, since the system presented a typical error of approximately 6.3 units.
The value obtained from of the proportion of variance shared between the fuzzy model and the EMIS indicator is $77 \%$, therefore, it can be said that the indicators share this percentage of common factors, which reaffirms the correspondence between theoretical and actual data.

Since there is a $33 \%$ value with a proportion of variance not explained, we should consider increasing the explanatory variables in order to achieve increased proportion of variance over the indicator of the fuzzy model. 


\section{References}

Angarita, A. A., Tabares, C. A., \& Rios, J. I. (2015). Definición de un modelo de medición de análisis de riesgos de la seguridad de la información aplicando lógica difusa y sistemas basados en el conocimiento. Entre Ciencia e Ingeniería, 9(17), 71-80.

Bolsa de Valores de Colombia BVC. (2017). Bolsa de Valores de Colombia, Un país todos los valores. Retrieved from http://www.bvc.com.co/pps/tibco/portalbvc/ Home/Empresas/Ranking + por+Capitalizaci\%$\mathrm{C} 3 \% \mathrm{~B} 3 \mathrm{n}+$ Burs\%C3\%A1til?action=dummy

Cortina, I. B., \& Robaina, D. A. (2010). Lógica difusa aplicada a la toma de decisiones. Ingenieria Industrial, 31(1), 1-5. Retrieved from http://search.ebscohost.com/login. aspx? direct $=$ true $\& \mathrm{db}=\mathrm{zbh} \& \mathrm{AN}=60258575$ \&lan$\mathrm{g}=$ es\&site=ehost-live\%5Cnhttp://content.ebscohost.com/ContentServer. asp? $\mathrm{T}=\mathrm{P} \& \mathrm{P}=\mathrm{AN} \& \mathrm{~K}=60258575 \& \mathrm{~S}=\mathrm{R} \& \mathrm{D}=\mathrm{z}-$ b h \& E b s c o C o n t e n t $=$ d G J y M N H r 7 E Sep7E4yOvqOLCmr0yep7FSr6m4SK+WxWXS\&ContentCustomer $=\mathrm{dGJyMPGrr}$

Euchner, J., \& Ganguly, A. (2014). Business Model Innovation in Practive. Research-Technology Management, o. Jg.(December), 33-40. https://doi.or$\mathrm{g} / 10.5437 / 08956308 \times 5706013$

Euromoney Institutional Investor Company EMIS. (2017). EMIS Benchmark. Retrieved from https:// www.emis.com/benchmark

Fogel, D., Liu, D., \& Keller, J. (2016). Fundamentals of Computational Intelligence. http://dx.doi. org/10.1002/9781119214403

Global Entrepreneurship Monitor GEM. (2015). ¿Qué es GEM? - Global Entrepreneurship Monitor. Retrieved from http://gem.ufm.edu/que-es-gem/

González-Santoyo, F., Gil-Lafuente, A. M., \& Flores Romero, B. (2015). Presupuesto base cero, gestión de la tesorería en contexto de incertidumbre (fuzzy logic): técnica y aplicación. Revista Nicolaita de Estudios Económicos, 10(1), 39-52.
Guerra, R. C. C., Smith, K. A., McKenna, A. F., Swan, C., Korte, R., Jordan, S., MacNeal, R. (2014). Innovation corps for learning: Evidence-based entrepreneurshipTM to improve (STEM) education. In Frontiers in Education Conference (FIE) Proceedings, 2014 IEEE, 1-5. https://doi.org/10.1109/FIE.2014.7044484

Johnson, R., \& Kuby, P. (2012). Elementary statistics. (1st ed.). Cengage Learning, Boston: Brooks/Cole

Kelley, D., Singer, S., \& Herrington, M. (2015). GEM global report 2015/16. Global Entrepreneurship Monitor, 1-78.

Kenney, J. (1966). Mathematics of statistics (1st ed.). Princeton, NJ: Van Nostrand.

Kolomvatsos, K., Anagnostopoulos, C., \& Hadjiefthymiades, S. (2012). A fuzzy logic system for bargaining in information markets. ACM Transactions on Intellent Systems and Technology (TIST), 3(2), 32. https://doi.org/10.1145/2089094.2089108

Marqués, F. (2009). Modelos para la economía y la empresa a través de Excel (1st ed.). San Fernando de Henares: RC Libros.

Osterwalder, A., \& Pigneur, Y. (2011). Generación de modelos de negocio. PlanetadeLibros.com, 285. https:// doi.org/10.1016/S0737-6782(96)90159-9

Proença, D., Nadali, A., \& Borbinha, J. (2015). A Pragmatic Risk Assessment Method Supported by the Business Model Canvas. Proceedings of the 5th International Symposium on Business Modeling and Software Design (BMSD 2015), 156-162. https://doi. org/10.5220/0005886501560162

Rojas López, M. D., Zuluaga Laserna, E., \& Valencia Corrales, M. E. (2014). Sistema de inferencia difuso para la valoración de empresas. Revista Ingenierías Universidad de Medellín, 13(24), 90-108.

Rojas, M., López, D., \& Rincón, C. (2012). Aplicación del método cybersin con lógica difusa en un sistema de control de gestión. Revista Ingenierías Universidad de Medellín, 11(20), 153-164. Retrieved from http:// www.scielo.org.co/scielo.php?script $=$ sci_arttex$\mathrm{t} \& \mathrm{pid}=\mathrm{S} 1692-33242012000100013 \& \operatorname{lng}=\mathrm{en} \& \mathrm{tl}-$ $\mathrm{ng}=$ 
Romero, M. C., Villalobos, J., \& Sanchez, M. (2015). Simulating the business model canvas using system dynamics. Computing Colombian Conference (10CCC), 2015 10th, 527-534. IEEE. Retrieved from https:// doi.org/10.1109/ColumbianCC.2015.7333469

Zadeh, L. A. (2008). Is there a need for fuzzy logic? Information Sciences, 178(13), 2751-2779. https://doi. org/10.1016/j.ins.2008.02.012
Zadeh, L. A. (1975). The concept of a linguistic variable and its application to approximate reasoning-I. Information Sciences, 8(3), 199-249. Retrieved from http://dx.doi.org/10.1016/0020-0255(75)90036-5

Zadeh, L. A. (1965). Fuzzy sets. Information and Control, 8(3), 338-353. Retrieved from https://doi. org/10.1016/S0019-9958(65)90241-X 